Tyndale Bulletin 65.1 (2014) 1-10

\title{
A FAKE COPTIC JOHN AND ITS IMPLICATIONS FOR THE 'GOSPEL OF JESUS'S WIFE'
}

\author{
Christian Askeland
}

\begin{abstract}
Summary
The recent revelation of a Coptic Gospel of John fragment from the same source as the so-called 'Gospel of Jesus's Wife' has decisively altered the discussion concerning the authenticity of the 'Gospel of Jesus's Wife' fragment. The Coptic John fragment is a crude copy from Herbert Thompson's 1924 edition of the 'Qau codex' and is a product of the same modern writing event as the 'Gospel of Jesus's Wife' fragment. Both texts are modern forgeries written on genuinely ancient fragments of papyrus. ${ }^{1}$
\end{abstract}

\section{Introduction}

Approximately a week before Easter 2014, the Harvard Theological Review released an issue largely dedicated to a Coptic papyrus fragment purportedly containing a 'Gospel of Jesus's Wife' (GJW), including a total of eight related articles. Several reports detailing Raman spectroscopic and multispectral imaging studies of the ink and radiometric datings appeared simultaneously on a dedicated website, contending that the GJW fragment is 'ancient.'2

Approximately eighteen months earlier, on 18 September 2012, at the Tenth International Congress of Coptic Studies in Rome, Karen L. King of the Harvard Divinity School had publicly announced the

1 The present article is not an edition of the new John fragment, but rather an argument for its inauthenticity and a summary of its relevance to establishing the inauthenticity also of the so-called 'Gospel of Jesus's Wife' fragment. I wrote my Cambridge $\mathrm{PhD}$ dissertation on the Coptic versions of John's gospel, a subject germane to the present discussion, in the Tyndale House library. The 'Qau codex' was published by the Cambridge scholar Herbert Thompson, and the codex itself is now in the Cambridge University Library.

2 'The Gospel of Jesus's Wife, 2014 update,' Harvard Divinity School, March 2014, http://gospelofjesusswife.hds.harvard.edu. Harvard Theological Review 107, no. 2 (2014). 
existence of the so-called 'Gospel of Jesus's Wife.' 3 Although a few initial sceptical observations pointed out the unusual palaeography and grammar of the GJW fragment, ${ }^{4}$ criticism quickly focused on its uncanny textual parallels to the Gospel of Thomas and the possibility of GJW being forgery. A crowd-sourced discussion resulted in a final paper by Andrew Bernhard which galvanized those opposed to hasty acceptance of GJW as being authentically ancient. ${ }^{5}$ By means of his 'patchwork theory,' Bernhard has demonstrated that several grammatical anomalies can all be explained by a forger's reliance upon a PDF file of a Coptic-English interlinear version of the Nag Hammadi Codex II version of the Gospel of Thomas which had been available online since 2002. ${ }^{6}$ Notably (in view of the role that online sources seem to have played in the forger's hoax), the main discussion concerning the authenticity of GJW occurred via the internet. ${ }^{7}$

According to copies of accompanying documents, as reported by King, a private owner had purchased the GJW fragment along with five other papyri in $1999,{ }^{8}$ one of which had been identified as a Coptic fragment of John's gospel. ${ }^{9}$ No details about the John fragment were

3 At the same time, King posted a draft of her article, "Jesus said to them, "My wife...": a new Coptic gospel papyrus' (2012), which was published this year in revised form in Harvard Theological Review 107, no. 2 (2014): 131-159.

4 Indeed, although King has cited him in her argument for authenticity, Malcolm Choat recognized the idiosyncrasy of the script of the GJW fragment, indicating that he could find no 'exact parallel' and that it is 'not similar to formal literary productions of any period.' Malcolm Choat, 'The Gospel of Jesus's Wife: a preliminary paleographical assessment,' Harvard Theological Review 107, no. 2 (2014): 161.

5 Andrew Bernhard, 'How the Gospel of Jesus's Wife Might Have Been Forged: A Tentative Proposal,' gospels.net, October 11, 2012, http:/www.gospels.net/gjw/ mighthavebeenforged.pdf; Francis Watson and Mark Goodacre, 'Revised Versions of Francis Watson's Articles on the Jesus Wife Fragment,' NT Blog, September 27, 2012, http://ntweblog.blogspot.de/2012/09/revised-versions-of-francis-watsons.html; Hugo Lundhaug and Alin Suciu, 'A Peculiar Dialectal Feature in the Gospel of Jesus's Wife, line 6,' alinsuciu.com, September 27, 2012, http://alinsuciu.com/2012/09/27/alin-suciuhugo-lundhaug-an-interesting-dialectal-feature-in-the-gospel-of-jesuss-wife-line-6/; Simon Gathercole, 'Gathercole on Jesus' Wife,' Tyndale House, Cambridge, September 19, 2012, http://www.tyndale.cam.ac.uk/ReJesusWife; Leo Depuydt, 'The Alleged Gospel of Jesus's Wife: Assessment and Evaluation of Authenticity,' Harvard Theological Review 107, no. 2 (2014): 172-89.

6 Michael Grondin, 'Grondin's Interlinear Coptic/English Translation of the Gospel of Thomas,' The Gospel of Thomas Resource Center, November 22, 2002, http://www. gospel-thomas.net/gtbypage_112702.pdf.

7 For a synopsis of the progress of this discussion, see Michael Grondin, 'A Question of Content: How I Saw the Internet Furor over the Jesus' Wife Fragment,' The Gospel of Thomas Resource Center, n.d., http://www.gospel-thomas.net/x_gjw.htm.

8 King, “'Jesus said to them, 'My wife ..."': a new Coptic papyrus fragment,' 153.

9 'The second document is a photocopy of a typed and signed letter addressed to $\mathrm{H}$.

U. Laukamp dated July 15, 1982, from Prof. Dr. Peter Munro (Freie Universität, 
available, nor any photographs. Scholars who were sceptical about the authenticity of GJW assumed that the John fragment and the four other fragments mentioned as being in the same private collection were genuinely ancient artefacts, a collection into which GJW might have been mixed in order to give it a seemingly legitimate pedigree. The two ink analyses concern not only the GJW fragment, but also the second papyrus fragment from the same source bearing parts of the Gospel of John in Coptic. Included in these two reports are photographs of the John fragment, which the present author was immediately able to recognize as a fake. ${ }^{10}$

\section{The Case for Forgery}

Although the 'patchwork theory' of composition was conclusive proof of GJW's inauthenticity for many, a further significant blow to the GJW fragment may indeed come from the related Gospel of John, now that photographs of it have become available, as mentioned above. This fragment is clearly a forgery, and, by all appearances, is the product of the same scribal hand as the GJW fragment. The two most prominent indicators of forgery for the Gospel of John fragment are (1) its textual affinity with the 1924 edition of the 'Qau codex'11 and (2) the decline of Lycopolitan as a Coptic literary dialect long before the time of the

Ägyptologisches Seminar, Berlin), stating that a colleague, Professor Fecht, has identified one of Mr. Laukamp's papyri as having nine lines of writing, measuring approximately 110 by $80 \mathrm{~mm}$, and containing text from the Gospel of John. Fecht is said to have suggested a probable date from the 2 nd to 5 th cents. C.E. Munro declines to give Laukamp an appraisal of its value but advises that this fragment be preserved between glass plates in order to protect it from further damage. The letter makes no mention of the $G J W$ fragment. The collection of the $G J W$ 's owner does contain a fragment of the Gospel of John fitting this description, which was subsequently received on loan by Harvard University for examination and publication (November 13, 2012).' Ibid., 154, fn. 107.

10 Christian Askeland, 'Jesus Had a Sister-in-Law,' Evangelical Textual Criticism, April 24, 2014, http://evangelicaltextualcriticism.blogspot.de/2014/04/jesus-had-uglysister-in-law.html. I am indebted to Gregg Schwendner and Malcolm Choat, who drew my attention to the images of the John fragment. An email requesting higher resolution images and permission to publish images in this journal remains unanswered. James T. Yardley and Alexis Hagadorn, 'Ink Study of Two Ancient Fragments through MicroRaman Spectroscopy' (May 13, 2014), 4, 6-7, http://gospelofjesusswife.hds.harvard. edu/ink-study; Joseph M. Azzarelli, John B. Goods, and Timothy M. Swager, 'Study of Two Papyrus Fragments with Fourier Transform Infrared Microspectroscopy' (Columbia University, December 27, 2013), 8, 11-12, http://gospelofjesusswife.hds. harvard.edu/fourier-transform-infrared-microspectroscopy.

11 Herbert Thompson, The Gospel of St. John according to the Earliest Coptic Manuscript (London: Bernard Quaritch, 1924). 
papyrus's harvesting. Several copying errors and other details further confirm the forgery, but the first two indicators each strongly indicate inauthenticity.

First, as demonstrated in the comparison below, all seventeen of the John fragment's line breaks coincide with those of the Qau codex exactly. The forger skipped every other line of Thompson's text when copying it onto his papyrus fragment. Perhaps, the forger's goal was to create a single-column codex from what he wrongly perceived to be a double-column codex due to Thompson's page layout. ${ }^{12}$ Together with

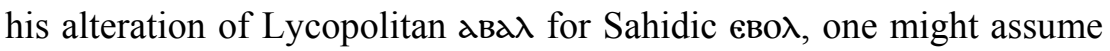
that his goal was somehow to confuse later scholars by dissimilating his forgery from Codex Qau. However, the forger failed to skip a line when he had to turn two pages of Thompson's edition, and thus the last line of the verso breaks the pattern and creates an impossible textual variant. ${ }^{13}$ Such an exact textual relationship as there is between the new John fragment and the Qau codex has no parallel in the extant Sahidic Bible tradition and can only reasonably be explained by the John fragment having been copied directly either from Thompson's edition of the Qau codex, or else from that codex itself, before it was damaged (since the fragment includes some of Thompson's restorations of lacunas in the Qau codex). ${ }^{14}$

Second, the occurrence of the Coptic Lycopolitan dialect does not fit with the papyrus upon which it is written. Peter Nagel states that 'after the fifth century no textual witness of [Lycopolitan] is attested, and one may conclude that by that time [Lycopolitan] had gone out of use as a literary language. ${ }^{15}$ This fragment was radiometrically dated by two

12 Thompson's edition presents two pages of text on each page of his edition, and the result clearly appears to represent a two-column codex.

13 The forger had to turn from Thompson page eight past plates 23/24 and 25/26 (each on a separate leaf) to page nine. The presence at this point of the stock phrase NeYxw | [Mmac $x$ ] $\epsilon$ 'they were saying...' hardly allows for a textual variant in the missing space in the John fragment. The restoration of the missing text is secure, and it is exactly one line of the Qau codex too short for the length of the lacuna, as measured by comparison with the other lines of the John fragment.

14 Stephen Emmel has made a codicological analysis of the John fragment which further indicates forgery. He also plans to include, in a small study of coincident line breaks in parallel Coptic manuscripts, a comparison with the line breaks from the only other known witness to Lycopolitan John, for which see Wolf-Peter Funk and Richard Smith, in: The Chester Beatty codex Ac. 1390: Mathematical School Exercises in Greek and John 10:7-13:38 in Subachmimic, by William M. Brashear, Wolf-Peter Funk, James M. Robinson and Richard Smith, Chester Beatty monographs 13 (Louvain: Peeters, 1990).

15 Peter Nagel, 'Lycopolitan (or Lyco-Diospolitan or Subakhmimic), Coptic Encyclopaedia (New York: Macmillan, 1991), vol. 8, 153. 
laboratories to $680-880^{16}$ and $640-800$ C.E., ${ }^{17}$ indicating that the papyrus plant from which the papyrus paper was manufactured was harvested at least a century and a half after the Lycopolitan dialect is believed to have disappeared. Furthermore, the Qau codex, which is the only likely source for the text of the new John fragment, was wrapped in a linen cloth, placed inside a jar and then buried, probably around the end of the fourth century. ${ }^{18}$ If the new John fragment were genuine we would have to make significant adjustments in our understanding of Coptic dialect history.

In addition, a list of mistakes committed by the copyist contrasts with the kinds of errors usually found in authentic ancient manuscripts. Alin Suciu has noted that the forger's substitution of Sahidic ево for Lycopolitan $\mathrm{d} B \mathrm{~B} \lambda$ cannot be reasonably reconciled with the dialectal context of the fragment. ${ }^{19} \mathrm{On}$ at least two occasions, the forger skipped one or more letters ( $\mathrm{kP}$ in kpine, recto line 7; and $\curlyvee$ in oүaN, recto line 3 ) and then appears to have abraded the area to mask the mistake not usual scribal practice in antiquity for correcting omissions. Joost Hagen has gathered a list of similar oddities in the fragment, his most telling observation, which he attributes to Frederic Krueger, being the manner in which the forger has written around a hole in the papyrus on

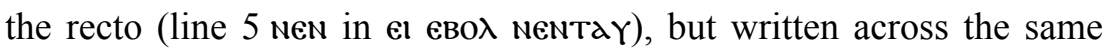
hole on the verso. ${ }^{20}$

16 Dates given are calibrated, 2-sigma and rounded (fract.mod. $0.85680 \pm 0.0033$ ); Gregory Hodgins, 'Accelerated Mass Spectrometry Radiocarbon Determination of Papyrus Samples,' Harvard Theological Review 107, no. 2 (2014): 166-69.

17 Ditto (fract.mod. $0.85030 \pm 0.00410$ ); Noreen Tuross, 'Accelerated Mass Spectrometry Radiocarbon Determination of Papyrus Samples,' Harvard Theological Review 107, no. 2 (2014): 170-71.

18 A perhaps related hoard of gold coins in mint condition was buried nearby, in view of the dates and condition of the coins either during or shortly after 361 C.E.; Guy Brunton, ed., Qau and Badari, vol. 3, Egyptian Research Account 50 (London: British School of Archaeology in Egypt, 1927), 29-30. Archaeological evidence suggests that the area was largely uninhabited after the Roman period.

19 Personal correspondence, 24 April 2014. Perhaps the forger was trying to simulate the Sahidic with Lycopolitan influence of the Gospel of Thomas.

20 Joost L. Hagen, 'Possible Further Proof of Forgery: A Reading of the Text of the Lycopolitan Fragment of the Gospel of John, with Remarks about Suspicious Phenomena in the Areas of the Lacunae and a Note about the Supposed Gospel of Jesus' Wife,' Alin Suciu, May 1, 2014, http://alinsuciu.com/2014/05/01/guest-postjoost-1-hagen-possible-further-proof-of-forgery-a-reading-of-the-text-of-thelycopolitan-fragment-of-the-gospel-of-john-with-remarks-about-suspiciousphenomena-in-the-areas-of-the-lac/. 


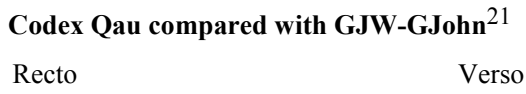

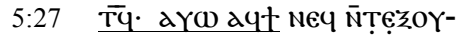
cld a тречіре мфеп' Хепо)н-

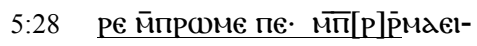
2є ХеоүноүоүноY М̄NHY

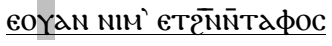

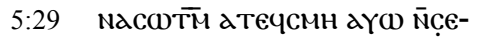

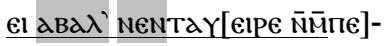
tnanoY a Yanacta[Cic nowne] nenTaYelpe M̄חe日aY a[Yana]-

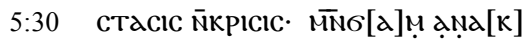

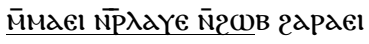

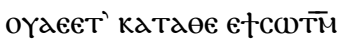
eEIpkpine. aүo Takpicic oYмHe Te Xeelac)ine ñcand-

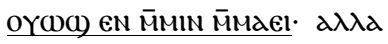

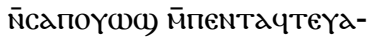

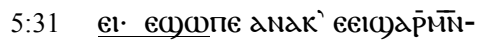

THC $\Delta E$ aYt

W AN חENTAYXITY apaY

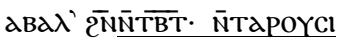

$6: 12$

$\triangle \in$ пахеч м̄мечмдентнс

Xecoore dzoYN $\overline{\mathrm{N}} \overline{\mathrm{N}} \lambda \epsilon-$

KMє N̄TaYceen€ Xekace

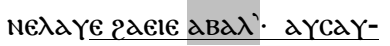

6:13

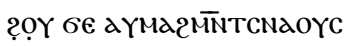

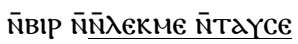

епе анетоүФм' ава入' $\overline{2 N}$

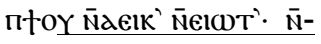

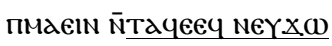

м̈мдс ХепєеІ мамне пе

\section{Two Fragments, One Forger}

At the end of this article, a digitally constructed comparison of the complete (or nearly complete) set of surviving characters is offered. If, as I believe, the same hand has created the GJW and John fragments, then the demonstrable inauthenticity of John conclusively indicates that GJW is also a forgery. The forger has written GJW in smaller letters, but apparently with the same writing implement, forcing more lines into a cramped space..$^{22}$ In the comparison below of the extant, clear letter forms, the reader should thus take account of the cruder calligraphy of GJW, and, likewise, should be aware that the GJW papyrus also has a rougher surface, also allowing for a coarser

21 The text is from Thompson, Gospel of St. John, 7-9. The extant parallels in the forgery are underlined. Characters highlighted in grey have been discussed above.

22 Stephen Emmel's provisional measurements of the character heights are $3 \mathrm{~mm}$ for the GJW fragment and $4 \mathrm{~mm}$ for the John fragment. 
appearance. In terms of basic composition, the characters share a similar generic appearance, despite inconsistencies within each fragment (especially $\mathrm{\epsilon}, \mathrm{N}, \Theta$ ).

In general, the characters are Latinized and unnuanced, which represents a pattern in itself, but a few peculiar character forms should remove any doubt that the hands of the two fragments are the same. Shai $\omega$ ) and Omega $\omega$ both have a middle vertical ascender which does not rise to the height of the outer ascenders. The inverse is true of $\mathrm{Mu}$ $\mathcal{M}$, with its middle descent dipping only halfway down. The pattern is the same in both fragments, and it probably betrays the forger's inexperience with palaeography. Similarly, Upsilon $\gamma$ often has a smaller than usual fork in both fragments. The vertical stroke of Ti + is the same length as the horizontal stroke, whereas the vertical is usually, if not always, longer. ${ }^{23}$

The lack of any substantive difference in the hands combined with these striking similarities confirms the general impressions offered by several other scholars on the matter. ${ }^{24}$ One may or may not be able to establish close parallels for the nondescript characters, or the peculiar characters referenced above, among other ancient papyri. Whatever the case, a distinct palaeographic pattern is shared by both fragments, confirming that the same hand has created them.

\section{Was the Accompanying Paperwork also Forged?}

Because the Lycopolitan John fragment shares the same script, similar ink $^{25}$ and the same writing instrument as the GJW fragment, the

23 Stephen Emmel first noted the peculiarity of $\mathrm{Ti}+$ in personal correspondence $(9$ May 2014).

24 Gregg Schwendner has posted no fewer than five analyses of the handwriting of these two fragments supporting the conclusion that they are the work of a single forger: wichita.academia.edu/GreggWSchwendner. Schwendner's paper on the inauthenticity of GJW is especially noteworthy: 'What Would Simulated Ancient Writing Look Like?' Roger Bagnall has described the script as 'if not in the same hand at least extremely close': Charlotte Allen, 'The Deepening Mystery of the "Jesus' Wife" Papyrus,' The Weekly Standard, April 28, 2014, http://www.weeklystandard.com/ blogs/deepening-mystery-jesus-wife-papyrus_787462.html. Likewise, Alin Suciu, 'Christian Askeland Finds the "Smoking Gun,"' alinsuciu.com, April 24, 2014, http:// alinsuciu.com/2014/04/24/christian-askeland-finds-the-smoking-gun/.

25 Ira Rabin (Max-Planck Institute, Berlin) is currently writing a critical response to the Harvard ink analysis which concluded that ' $[\mathrm{t}] \mathrm{he}$ ink or inks used in GJW are similar to, but distinct from, the ink used for the Gospel of John manuscript.' James T. Yardley and Alexis Hagadorn, 'Characterization of the Chemical Nature of the Black 
inauthenticity of the one entails the inauthenticity of the other. The patchwork theory for how the text of GJW was composed stands vindicated. Furthermore, the three modern documents associated with the papyri (a 1982 typed letter signed by Munro, an anonymous handwritten note referring to Fecht and a 1999 bill of sale mentioning the anonymous owner) are probably also inauthentic, at least in part, as these documents reference the two manuscripts in question.

A LiveScience reporter, Owen Jarus, has scrutinized certain aspects of the 1999 bill of sale, determining that the anonymous owner almost certainly did not purchase the fragments from Hans-Ulrich Laukamp, based on the statements of Laukamp's friends and colleagues. Furthermore, according to Jarus, Laukamp's purported purchase of the fragments in Potsdam in 1963 is also likely a piece of fiction, as Laukamp lived in West Berlin at the time and 'couldn't have crossed the Berlin Wall into Potsdam. ${ }^{26}$

Because the Lycopolitan John forgery resembles the fragment mentioned in the typed note both with regard to its size (appr. $11 \times$ $8 \mathrm{~cm}$, width $\times$ height) ${ }^{27}$ and its content ('nine lines of writing'), ${ }^{28}$ one could suppose that this typed note is either a forgery or a re-purposed original used with a custom-made John forgery. Although the note is reportedly signed by Munro, this signature has apparently not yet been evaluated against trustworthy samples.

Of the supporting documents, perhaps the boldest forgery is the handwritten note referencing [Gerhard] Fecht's opinion concerning the GJW fragment. ${ }^{29}$ Barring some new revelation to the contrary, the handwriting in this note must be that of either the forger himself or an accomplice. King has not seen the original documents, only a

Ink in the Manuscript of the Gospel of Jesus's Wife through Micro-Raman Spectroscopy,' Harvard Theological Review 107, no. 2 (2014): 164.

26 Owen Jarus, "'Gospel of Jesus's Wife": Doubts Raised about Ancient Text,' LiveScience.com, April 22, 2014, http://www.livescience.com/45020-gospel-of-jesuswife-questioned.html.

27 According to figures 7-8 on pages eleven and twelve of Azzarelli et al.'s report available on the Harvard website, the John fragment is $5 \times 3.5 \mathrm{~cm}$. However, the scale in those figures must be wrong. A picture on page four of the report by Yardley and Hagadorn shows the GJW and John fragments side-by-side, and the John fragment is approximately twice the size of the GJW.

28 King, "“Jesus said to them, 'My wife ..."”: a New Coptic Papyrus Fragment,' 154, fn. 107.

29 'Professor Fecht glaubt, daß der kleine ca. $8 \mathrm{~cm}$ große Papyrus das einzige Beispiel für einen Text ist, in dem Jesus die direkte Rede in Bezug auf eine Ehefrau benutzt. Fecht meint, daß dies ein Beweis für eine mögliche Ehe sein könnte.' Ibid., 153, fn. 106. 
photocopy of the bill of sale and 'scanned copies of two photocopies' of the handwritten and typed notes. ${ }^{30}$

In terms of reconstructing just when the forgery was committed, the following dates are significant. Accepting the patchwork theory for the creation of GJW as correct, the forger relied upon Michael Grondin's PDF file of the Gospel of Thomas in Coptic and English, which was not available on line earlier than 22 November, 2002. ${ }^{31}$ If the forger also depended on the internet for access to Thompson's edition of the Qau codex, then he could not have created the John fragment before 2005. ${ }^{32}$ Perhaps, however, the most important dates are the deaths of the persons cited in the accompanying documents (Hans-Ulrich Laukamp, 6 December 2002;33 Gerhard Fecht, 13 December 2006; Peter Munro, 2 January 2009), whose deaths predate the appearance of the papyri and the documents referencing their activity. ${ }^{34}$ Indeed, the Gospel of Jesus's Wife fragment and most, if not all, of the related materials may well have been manufactured less than a year or two before the July 2010 email from the anonymous current owner to King, inviting her to 'look at a Coptic papyrus in his collection.'35

30 Ibid., 153.

31 Grondin, 'A Question of Content.'

32 Mark Goodacre, 'Illustrating the Forgery of Jesus' Wife's Sister Fragment,' NT Blog, April 25, 2014, http://ntweblog.blogspot.de/2014/04/illustrating-forgery-of-jesuswifes.html.

33 I would like to thank Owen Jarus, who emailed me an estate tax document confirming Laukamp's precise date of death.

34 For a comprehensive chronology, see Stephen Goranson, 'Tentative Chronology on Coptic 'Jesus Wife' Fragment,' NT Blog, April 28, 2014, http://ntweblog.blogspot.de/ 2014/04/tentative-chronology-on-coptic-jesus.html.

35 King, “"Jesus said to them, 'My wife ..."': a New Coptic Papyrus Fragment,' 154. The present author does not believe the current owner to be complicit in the forgery, but probably rather to be a philanthropist with the best interests of Karen King and the Harvard Divinity School at heart. 
$z=\pi-0$ I $\theta$ o $\infty$

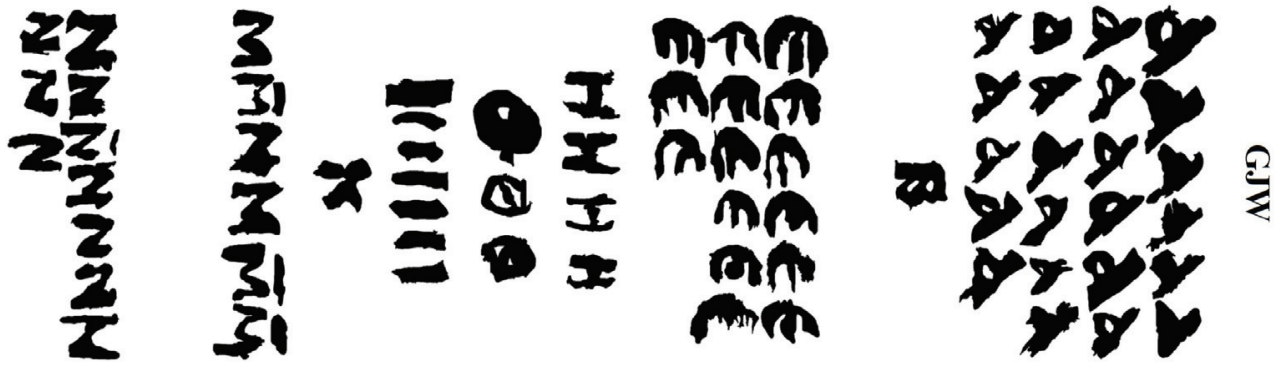

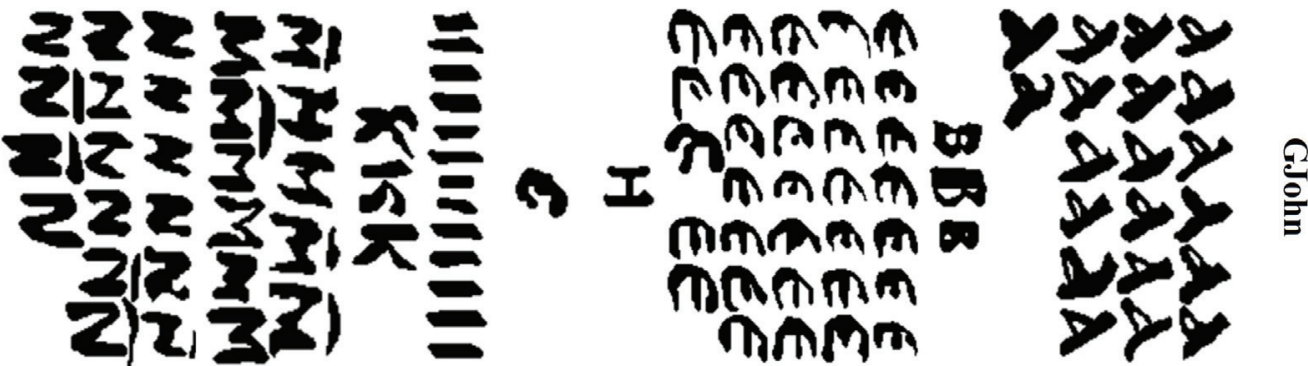

$\forall \sim \varepsilon \varepsilon \varepsilon \prec+t \circ \sigma \exists 0$

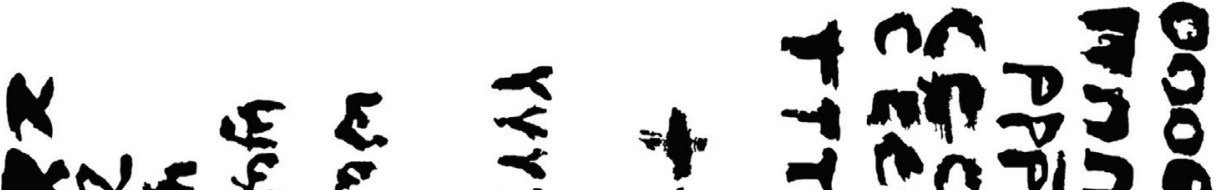

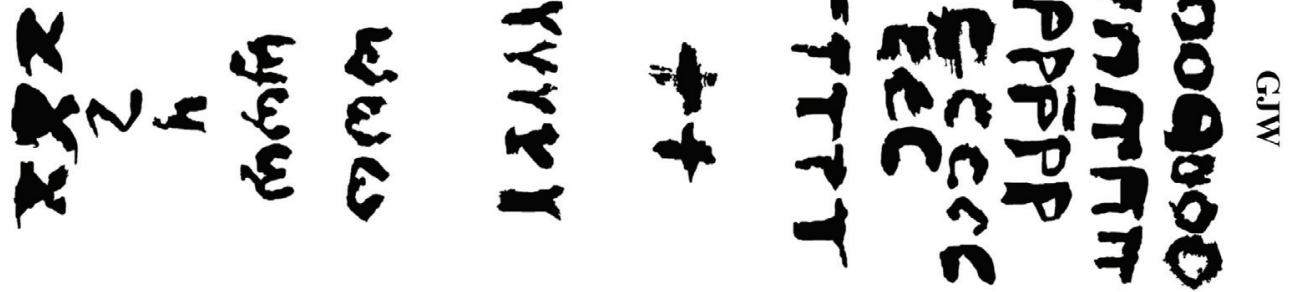

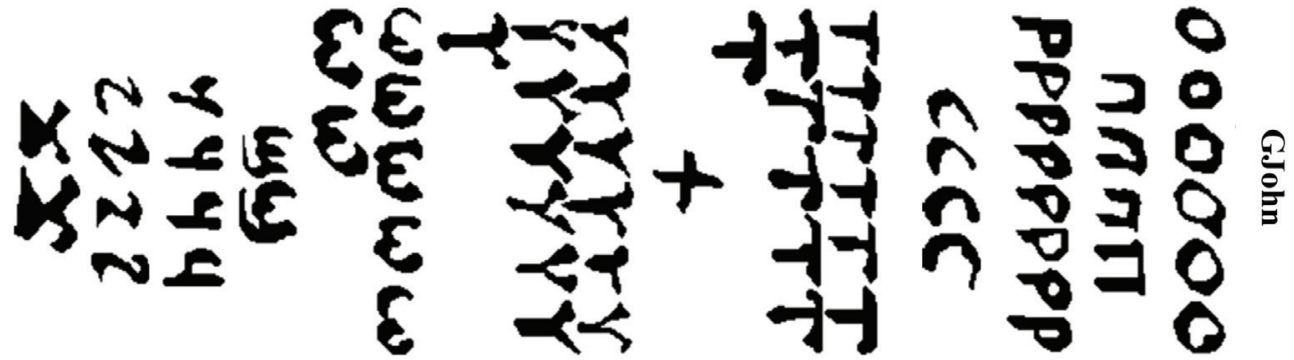

